DOI: 10.17707/AgricultForest.62.4.23

\author{
Ivan V. ZMITROVICH, \\ Margarita A. BONDARTSEVA, Mariya V. SIDELNIKOVA ${ }^{1}$
}

\title{
NOTEWORTHY POLYPORES OF PUSHKIN CITY NEAR THE SAINT PETERSBURG (RUSSIA), THE RESERVE OF OLD-GROWTH TREES. 2. CERIOPORUS VARIUS AND C. LEPTOCEPHALUS
}

\begin{abstract}
SUMMARY
The paper continues a series focused on noteworthy polypores associated presumably with old-growth broadleaf trees in Pushkin (Tsarskoye Selo) ensemble near St. Petersburg. Some nemoral species complexes are reserved here due to protection of old-growth trees over this area. The species in focus of the present paper are Cerioporus (Polyporus) varius and its sib, C. leptocephalus (Polyporaceae, Agaricomycetes), both widely distributed in deciduous and mixed forests, but associated mainly with old trees and stumps. These are closely related species differing by morphogenetic features. Five habitats of $C$. varius and four habitats of $C$. leptocephalus were revealed in the Pushkin city. All these are documented, and an enlarged morphological and ecological description of both species is given. The rare form C. varius f. circumpurpurascens was epitypified and re-combined in the genus Cerioporus.
\end{abstract}

Keywords: Polyporaceae, polypores, polyporoid fungi, parks, oldgrowing trees, Tsarskoye Selo park ensemble

\section{INTRODUCTION}

The paper continues a series devoted to polypores attached to old-growth leaf trees protected in the Pushkin city (known also as Tsarskoye Selo, Russia), where urban sites and old parks form a peculiar mosaic and levels of technogenic pressure are sufficiently reduced (Zmitrovich, 2016). The presence of old trees, especially of broad-leaf ones over this area makes favorable conditions for development of some polypore species which are less presented in neighboring managed forests. The main purpose of this series is enlarged description of ecological polymorphism of noteworthy polypores species found in Pushkin city (Tsarskoye Selo) territory and representation of habitats of these organisms.

Since XVIII century, the species in question have been described as Boletus leptocephalus (Jacquin, 1778) and B. varius (Persoon, 1796). After E. M. Fries study (1821) and till the most recent times, both species have been regarded into Polyporus genus, however molecular phylogenetic studies show their

\footnotetext{
${ }^{1}$ Ivan V. Zmitrovich, (corresponding author: IZmitrovich@binran.ru, iv_zmitrovich@mail.ru), Margarita A. Bondartseva , Komarov Botanical Institute - St. Petersburg, 2. Prof. Popov str., 197376 RUSSIA Mariya V. Sidelnikova (kapa0505@mail.ru), Saint-Petersburg State Agrarian University - St. Petersburg, Pushkin, 2. St. Petersburg roadway, 196601 RUSSIA.

Notes: The authors declare that they have no conflicts of interest. Authorship Form signed online.
} 
position within an independent genus Cerioporus (Zmitrovich \& Kovalenko, 2016).

In XX century, a tendency to merging of two species appeared (Bondartsev, 1953; Gilbertson \& Ryvarden, 1987; Bondartseva, 1998), although Overholts (1953) was sure that Polyporus varius differed from P. elegans (latter synonym of $P$. leptocephalus). Such a view is obvious from original descriptions and drawings of these taxa. As it is seen from Fig. 1, the original drawing of Boletus leptocephalus with a minute clear pileus and a pronounced subcentral stalk is contrasted to Bolton's (1788) drawing of B. lateralis which was selected by Persoon (1796) as an illustration of $B$. varius - a clustered polypore with a lateral stem and an undulating colored margin.

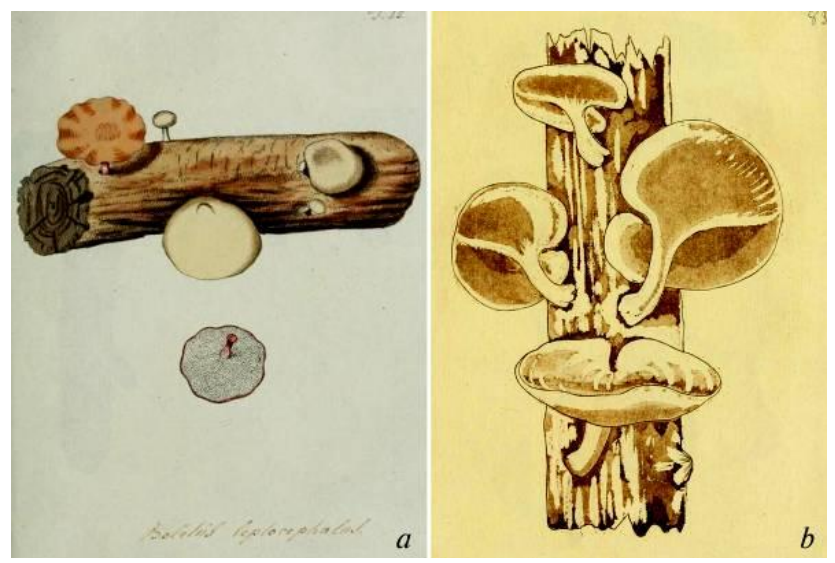

Figure 1. Original drawing of Boletus leptocephalus by Jacquin (1778) with a minute clear pileus and a pronounced subcentral stalk $(a)$, and Bolton's (1788) drawing of $B$. lateralis which was selected by Persoon (1796) as a figure of $B$. varius $(b)$.

Due to highly similar nature of basidiome texture, surfaces structure and micromorphology in both taxa, their differences can be interpreted as having of ecotypic, but not species nature, but we prefer keeping both species separately, similarly to another member of the complex, C. choseniae (Zmitrovich et al., 2014), at least until an exhaustive molecular testing. The current experience on another species pair in the genus Cerioporus, namely Cerioporus squamosus/C. rangiferinus (Zmitrovich et al., 2017), shows that morphogenetic differences connected to the reaction to light of aerial mycelium can lead to a lineages divergence. $C$. leptocephalus as well as $C$. rangiferinus has an extended displaced stipe, covered with a black multilayered crust, its cap is not extensively developed. On the contrary, $C$. varius has an expanded cap and a modest (often reduced) stipe with a not expressed crust - even if it is covered by dark pruina.

Both $C$. varius and $C$. leptocephalus have a cosmopolitan, but mainly Holarctic distribution, however occupy rather diverse niches. C. varius is associated mainly with standing old trees, where it often grows as a pathogenic 
saprotroph, whereas $C$. leptocephalus (=Polyporus elegans, $=P$. nummularius) is associated with old stumps and fallen branches (Bondartsev, 1953; Bondartseva et al., 2014). A global substrate range, known for $C$. varius with inclusion of $C$. leptocephalus only, contains such tree genera as Acer, Aesculus, Alnus, Betula, Buxus, Castanea, Corylus, Crataegus, Eucalyptus, Fagus, Frangula, Fraxinus, Juglans, Malus, Ostrya, Populus, Prunus, Pyrus, Rhamnus, Ribes, Robinia, Rubus, Quercus, Salix, Sambucus, Sorbus, Tilia and Ulmus (Ryvarden \& Melo, 2014). In Denmark, Cerioporus varius is protected having a «Least concern» (LC) status (The Danish..., 2016). Over the Pushkin area these interesting polypore species have a certain distribution.

\section{Territory studied}

\section{MATERIAL AND METHODS}

Tsarskoye Selo (Pushkin) city occupied hilly landscape on border of the Prinevsky Lowland and the Izhora Plateau in 15 kilometers to the south of St. Petersburg on approx. $59.75^{\circ} \mathrm{N}$ and $30.36^{\circ} \mathrm{E}$ crosshairs. The highest areas lie here about $100 \mathrm{~m}$ above the sea level. Park zone of Pushkin (Tsarskoye Selo) ensemble occupies the area of 704 hectares (Zmitrovich, 2016).

\section{Material collection}

A total of thirty $\mathrm{km}^{2}$ of protected territory were under the monitoring since 2012. Old-growth leaf-trees phytosphere was examined on the occurence of the polypore species. The fruitbodies were fixed on photo or collected in the case of necessity of study their morphology. In the laboratory, $-20{ }^{\circ} \mathrm{C}$ freezing of material followed by drying were carried out. The material is kept in mycological herbarium of the Komarov Botanical Institute of the Russian Academy of Sciences (LE).

\section{Material elaboration}

The macroscopic descriptions were based on a study of fresh and dried specimens. Microscopic preparations were mounted from dried material in Melzer's solution, $10 \%$ ammoniacal Congo Red and 5\% aqueous solution of $\mathrm{KOH}$, using a LOMO Micmed-6 light microscope. The hyphal system was revealed and described using the updated technique (Zmitrovich et al., 2009). For the spore size measure were used 30 spores of every sample. For preparations were used distilled water and Melzer's solution. The taxonomic position of the species was based on recent molecular studies (Zmitrovich, Kovalenko, 2015). The higher taxa are given according to Hibbett et al. (2014).

\section{RESULTS AND DISCUSSION Agaricomycetes \\ Polyporales \\ Polyporaceae}

Cerioporus leptocephalus (Jacq. : Fr.) Zmitr. et Kovalenko, Int. J. Medicinal Mushrooms 18(1): 33, 2016. - Bas.: Boletus leptocephalus Jacq., Miscell. Austriac 1: 142, 1778 ex Fr., Syst. Mycol. 1: 349, 1821 [ut Polyporus 
leptocephalus]. $\equiv$ Coltricia leptocephala (Jacq. : Fr.) Gray, Nat. Arr. British Pl. 1: 645, 1821. $\equiv$ Polyporellus leptocephalus (Jacq. : Fr.) P. Karst., Medd. Soc. Fauna Fl. Fennica 5: 38, 1879. इ Leucoporus leptocephalus (Jacq. : Fr.) Quél., Enchir.: 166, 1886. = Boletus elegans Bull., Herb. France 2: 76, 1782. $\equiv$ Polyporellus elegans (Bull.) P. Karst., Medd. Soc. Fauna Fl. Fennica 5: 37, 1879. $\equiv$ Melanopus elegans (Bull.) Pat., Essai: 80, 1900. = Boletus nummularius Bull., Herb. France 3: tab. 124, 1883. $\equiv$ Coltricia nummularia (Bull.) Gray, Nat. Arr. British Pl. 1: 644, 1821. 三 Polyporus nummularius (Bull.) Fr., Observ. Mycol. 1: 123, 1815. = Boletus nigripes With, Arr. British Pl. 4: 316, 1796. = Polyporus elegans Fr., Epicr.: 440, 1838.

Icon.: Jacqiun (1778: fig. 12 ut Boletus leptocephalus), Sowerby (1797: tab. 89 ut B. nummularius).

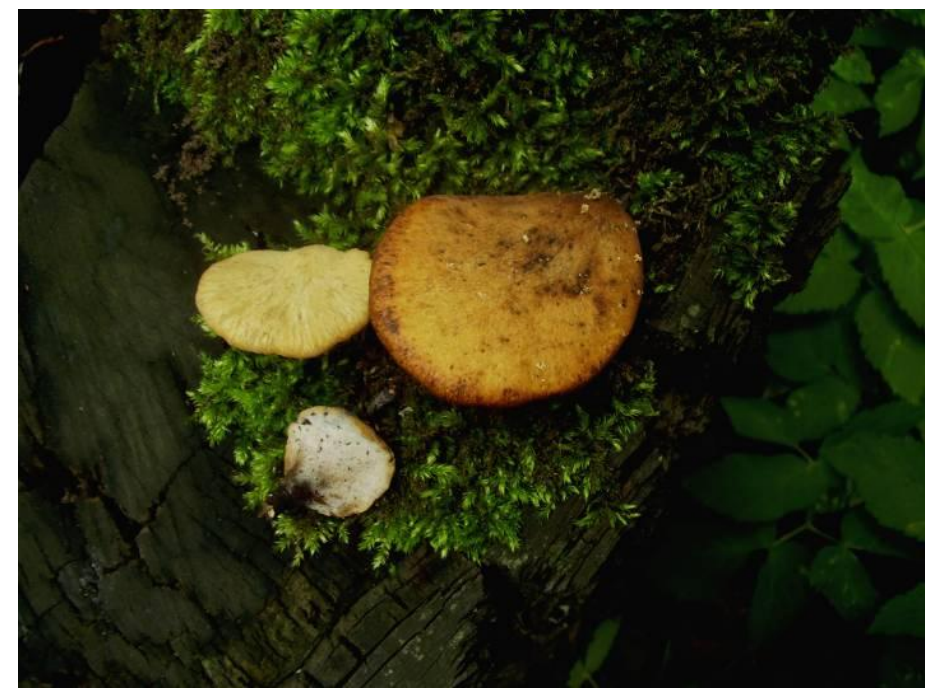

Figure 2. Cerioporus leptocephalus found on Tilia cordata stump on the square near Pushkin administration with $T$. cordata and Quercus robur (59 $\left.43^{\prime} 23^{\prime \prime} \mathrm{N}, 30^{\circ} 25^{\prime} 02^{\prime \prime} \mathrm{E}\right)$.

Basidiomata annual, solitary, differentiated into single or branched stipe and rather minute pilei. Pilei (0.8)1-3(6) $\mathrm{cm}$ in diam., $0.1-0.5 \mathrm{~cm}$ thick at the base, spathulate, concave, convex or plane, in sublateral forms their length exceeds a width. Upper surface even, covered with ivory to stramineous cuticle of fine radially undergrown-fibrillose texture. Margin isochromatic, initially straight, then incurved, as a rule not undulating, but sometimes sinuous in outline, especially near the base. Stipe up to $10 \mathrm{~cm}$ long and $-5 \mathrm{~mm}$ in crosssection, elongated and deeply rooted into substrate, in some cases twicebranched, sometimes undulating, more or less isodiametric, central or eccentric, covered with brown-black to radical black crust. Hymenophore as a single tube layer $0.5-3.2 \mathrm{~mm}$ thick well differentiated from the context; pore surface initially white, then isabelline to cinnamon, in medial states cream or honey yellow; pores 3-5 per $\mathrm{mm}$, roundish, rather thick-walled, isodiametric in large areas. The 
context $0.1-2 \mathrm{~mm}$ thick, homogeneous, dense, cream to clay-yellow. The consistency is tough in fresh, cretaceous at drying (Fig. 2).

Hyphal system dimitic with skeleto-binding hyphae. Generative hyphae 1.5-5 $\mu \mathrm{m}$ in diam., with prominent clamp connections, regularly branched, inamyloid, hyaline. Skeleto-binding hyphae $1.5-6.5 \mu \mathrm{m}$ in diam., as a rule with inflated axial element and dendritic appendages, slightly thick-walled to subsolid, hyaline or yellowish. Caulocystidia $20-55 \times 7-10 \mu \mathrm{m}$, clavate-cylindric, thickwalled to subsolid, yellowish-brown, arranged into 2-4-layered palisade which forms a stipe crust. Basidia 18-30 × 5-9 $\mu \mathrm{m}$, clavate, with a basal clamp connection, 4-spored. Basidiospores 8.5-9.5 $\times 2.8-3.9 \mu \mathrm{m}$, fusoid, with a minute apiculus, hyaline, thin-walled, inamyloid, acyanophilous.

Substrates and ecology. Cerioporus leptocephalus grows on stumps and fallen twigs of trees and shrubs causing a white rot. Basidiomata exist during a single season (Jule-October), but in warm winters they can stay as bodies with decolorated pilei and coffee-colored hymenophore.

The most typical habitats of this fungus are shrubs thickets within broadleaf stands, with abundant wood debris (Fig. 3).

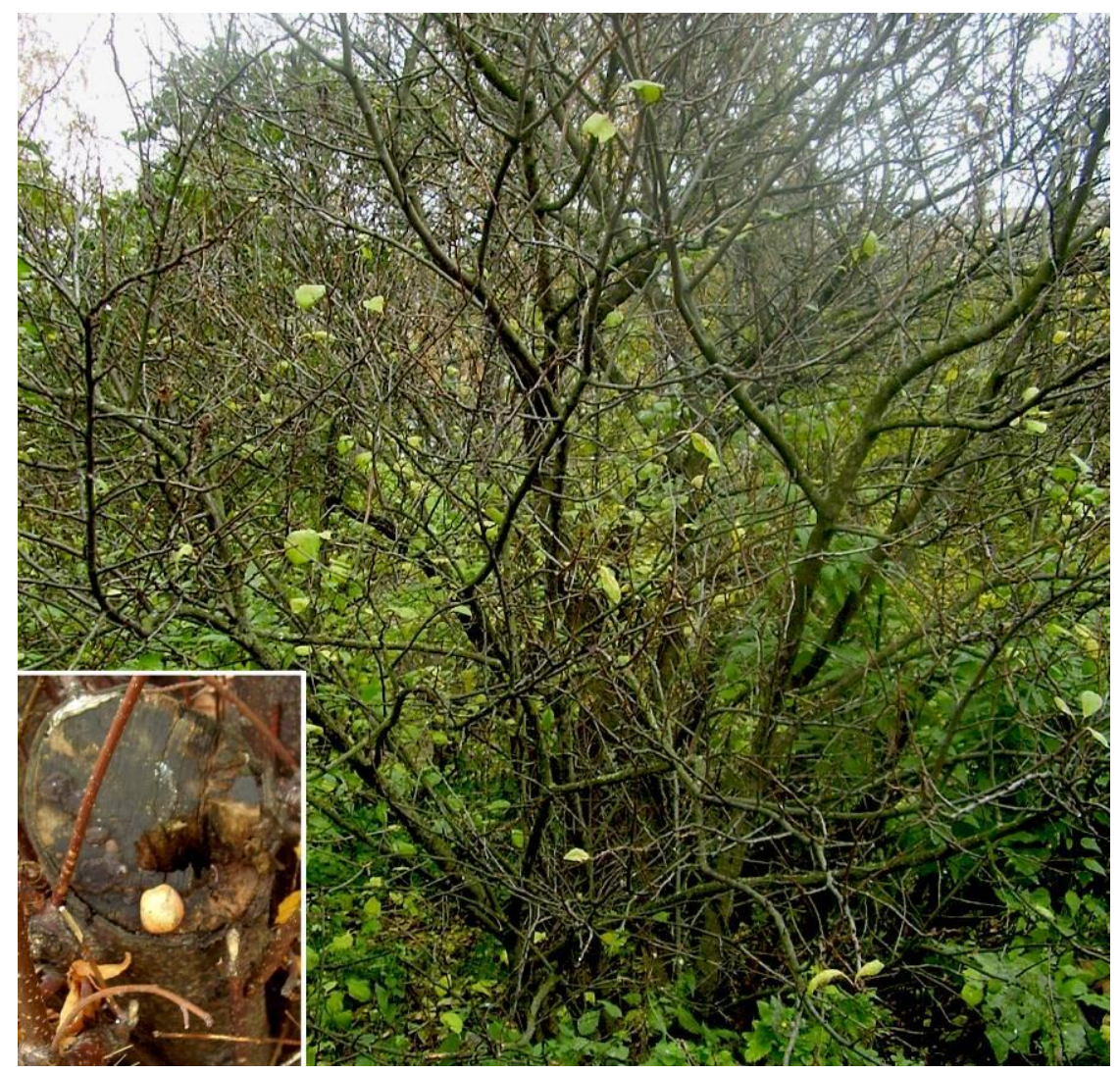

Figure 3. Typical habitat of Cerioporus leptocephalus in the Pushkin city. 
Distribution. EUROPE: United Kingdom, Norway, Sweden, Finland, France, Germany, Austria, Poland, Czech Republic, Switzerland, Montenegro, Russia; OCEANIA: New Guinea; AUSTRALIA: New Zealand; NORTH AMERICA: USA, Canada; SOUTH AMERICA: Brazil (Global.., 2016).

Table 1. Records of Cerioporus leptocephalus on the Pushkin city (Tsarskoye Selo) territory

\begin{tabular}{|c|c|c|c|c|}
\hline $\mathrm{N}$ & Coordinates & Locality, habitat & Substrate & Specimen \\
\hline 1. & $\begin{array}{l}59^{\circ} 43^{\prime} 36^{\prime \prime} \mathrm{N} \\
30^{\circ} 22^{\prime} 02^{\prime \prime} \mathrm{E}\end{array}$ & $\begin{array}{l}\text { Fermsky Park, mixed old } \\
\text { stand with Acer platanoides, } \\
\text { Fraxinus excelsior, Malus } \\
\text { sylvestris, Ribes spp. }\end{array}$ & $\begin{array}{l}\text { Ribes rubrum } \\
\text { twigs }\end{array}$ & $\begin{array}{l}\text { Cerioporus } \\
\text { leptocephalus } \mathrm{f} . \\
\text { nummularius (LE } \\
\text { 287637) }\end{array}$ \\
\hline 2. & $\begin{array}{l}59^{\circ} 43^{\prime} 23^{\prime \prime} \mathrm{N} \\
30^{\circ} 25^{\prime} 02^{\prime \prime} \mathrm{E}\end{array}$ & $\begin{array}{l}\text { The square near Pushkin } \\
\text { administration with Tilia } \\
\text { cordata and Quercus robur }\end{array}$ & $\begin{array}{l}\text { Tilia cordata } \\
\text { stumps }\end{array}$ & $\begin{array}{c}\text { typical form } \\
-\end{array}$ \\
\hline 3. & $\begin{array}{l}59^{\circ} 42^{\prime} 53^{\prime \prime} \mathrm{N} \\
30^{\circ} 25^{\prime} 21^{\prime \prime} \mathrm{E}\end{array}$ & $\begin{array}{l}\text { Clinic of Eberman park with } \\
\text { Tilia cordata, Padus avium, } \\
\text { Frangula alnus, Sorbaria } \\
\text { sorbifolia }\end{array}$ & $\begin{array}{l}\text { Padus avium } \\
\text { and Sorbaria } \\
\text { sorbifolia } \\
\text { stumps, Tilia } \\
\text { cordata fallen } \\
\text { twigs }\end{array}$ & $\begin{array}{c}\text { typical form } \\
-\end{array}$ \\
\hline 4. & $\begin{array}{l}59^{\circ} 44^{\prime} 41^{\prime \prime} \mathrm{N}, \\
30^{\circ} 25^{\prime} 42^{\prime \prime} \mathrm{E}\end{array}$ & $\begin{array}{l}\text { Alexey Tolstoy Boulevard, } \\
\text { intra-quarter gardening with } \\
\text { Ulmus glabra, Acer } \\
\text { platanoides, Tilia cordata, } \\
\text { Salix fragilis, S. alba }\end{array}$ & $\begin{array}{l}\text { Tilia cordata } \\
\text { stump, Ulmus } \\
\text { glabra twigs }\end{array}$ & $\begin{array}{c}\text { typical form } \\
-\end{array}$ \\
\hline
\end{tabular}

The distribution of this species over Pushkin (Tsarskoye Selo) territory is rather scarce. Only 4 habitats of C. leptocephalus are revealed (Table 1; Fig. 4). All these are presented by shady micro-sites covered by non-cut shrubs.

\section{Morphological variability.}

In the field, $C$. leptocephalus can be recognized due to its minute basidiomata with ivory to clay minute pilei on black-colored long isodiametric stipes. The pileus outline can be roundish, but in some cases it is spathulate or shell-like. Upperside is characterized by fine fibrillose internal structure and homogeneous light coloration. In old exemplars, upper surface staying clay-buff to pale and so fibrillose structure is invisible. The stipe in this species is furnished by a black-colored crust reaching a hymenophore area.

There are two main forms of the species $-C$. leptocephalus $\mathrm{f}$. leptocephalus, having an elongated (up to 5-6 cm) pileus and an eccentric stipe and Cerioporus leptocephalus f. nummularius (Bull.) Bondartseva, Zmitr. et Sidelnikova comb. et stat. nov. (Bas.: Boletus nummularius Bull., Herb. France 3: tab. 124, 1883; MB 818684), characterized by a small (up to $3 \mathrm{~cm}$ in diam.) roundish (nummularius $=$ coin-like) pilei on subcentral stems. Both forms are presented in the area studied (Table 1). 


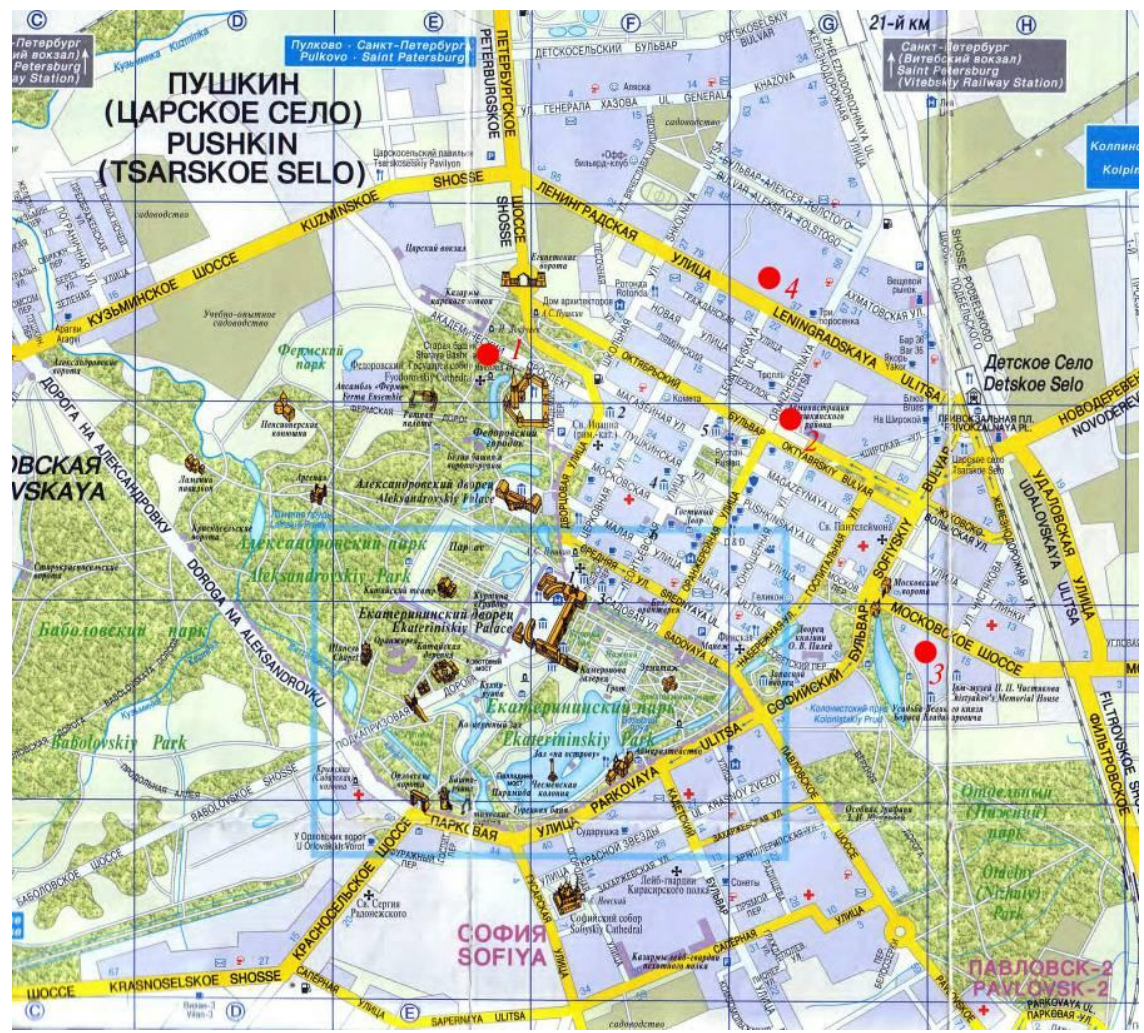

Figure 4. Pushkin city quarter plan with indications of habitats of Cerioporus leptocephalus (red circles). The numbers are corresponded to those in Table 1.

Cerioporus varius (Pers. : Fr.) Zmitr. et Kovalenko, Int. J. Medicinal Mushrooms 18(1): 33, 2016. - Bas.: Boletus varius Pers., Observ. Mycol. 1: 85, 1796 ex Fr., Syst. Mycol. 1: 352, 1821 [ut Polyporus varius]. $\equiv$ Polyporellus varius (Pers. : Fr.) P. Karst., Medd. Soc. Fauna Fl. Fennica 5: 37, 1879. 三 Melanopus varius (Pers. : Fr.) Pat., Hymen. Eur.: 137, 1887. = Boletus calceolus Bull., Herb. France 8: tab. 360, 1786. = B. lateralis Bolton, Hist. fung. Halifax 2: 83, 1788. = B. ramulosum J. F. Gmelin, Syst. Nat. 2(2): 1435, 1792. = Polyporus petalodes Fr., Epicr.: 444, 1838. = P. blanchetianus Berk. et Mont., Ann. Sci. Nat. Bot. 11: 238, 1849. = P. boltonii Rostk. in Sturm, Deutschl. Fl. 7: 47, 1848. $=P$. leprodes Rostk. in Sturm, Deutschl. Fl. 7: 33, 1848. = P. gintlianus Velen., České Houby 4-5: 687, 1922.

Icon.: Bolton (1788: fig. 83 ut Boletus lateralis), Bulliard (1796: pl. 360 ut B. calceolus), Niemelä (2005: fig. 227 ut Polyporus leptocephalus), Bernicchia (2010: p. 748 ut $P$. varius), Melo \& Ryvarden (2014: fig. 283 ut $P$. varius).

Basidiomata annual, clustered, rarely solitary, differentiated into wide pileus and eccentric to lateral narrowing stem. Pilei $3-8(10) \mathrm{cm}$ wide, $0.3-0.8 \mathrm{~cm}$ thick at the base, dimidiate, snell-like or infundibuliform, the pileus width as a rule exceeds its length. Upper surface glabrous to matt, covered with cream to 
clay or pale-ochraceous cuticle of radially-fibrillose internal of external texture; in some cases can be radially ridged. Margin colored - purple-brown or cinnamon-brown, initially straight, then incurved, as a rule undulating or sinuous. Stipe up to $3 \mathrm{~cm}$ long and $-8 \mathrm{~mm}$ in cross-section, rather short, straight, more or less wedge-shaped, eccentric or lateral, naked or covered with brownish to brownish-black pruina, but without a thick crust formation. Hymenophore as a single tube layer, $0.8-5.5 \mathrm{~mm}$ thick, well differentiated from the context; pore surface initially white, then honey-yellow to clay-buff; pores 4-8 per mm, roundish, thick- to thin-walled, isodiametric in large areas and rather sinuous near the base. The context $0.3-5 \mathrm{~mm}$ thick, homogeneous, dense, cream to buff. The consistency is tough in fresh, suberose-coriaceous to cretaceous at drying (Fig. 5).

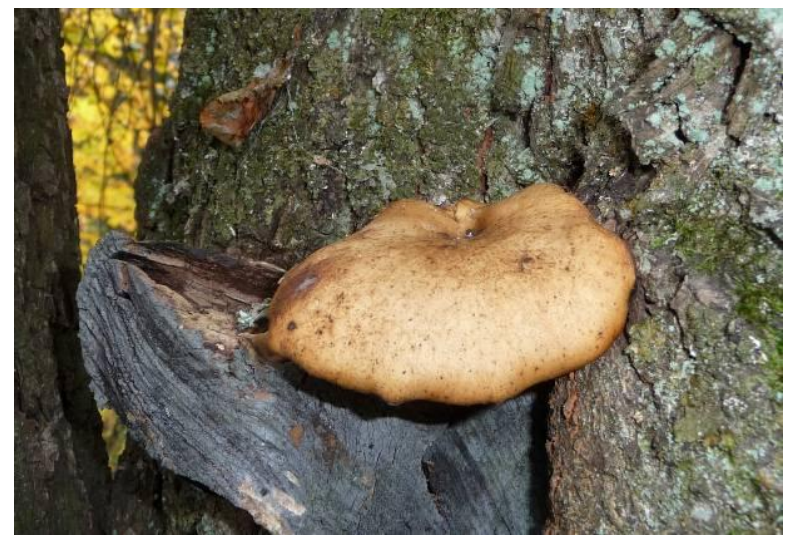

Figure 5. Cerioporus varius found on Tilia cordata notch in the vicinities of SaintPetersburg State Agrarian University, T. cordata stands (59 43'51'N, 30²3'25”E).

Hyphal system dimitic with skeleto-binding hyphae. Generative hyphae 1.5-5.5 $\mu \mathrm{m}$ in diam., with prominent clamp connections, regularly branched, inamyloid, hyaline. Skeleto-binding hyphae $1.5-7.0 \mu \mathrm{m}$ in diam., as a rule with inflated axial element and dendritic appendages, slightly thick-walled to subsolid, hyaline or yellowish. Caulocystidia $15-55 \times 5-10 \mu \mathrm{m}$, clavate-cylindric, thickwalled to subsolid, yellowish-brown, lying into 1-layered loose palisade which forms a stipe pruina. Basidia $18-35 \times 5.5-9.5 \mu \mathrm{m}$, clavate, with a basal clamp connection, 4-spored. Basidiospores 8.5-11.5 × 2.8-3.9 $\mu \mathrm{m}$, fusoid, with a minute apiculus, hyaline (often multiguttulate), thin-walled, inamyloid, acyanophilous.

Substrates and ecology. Cerioporus varius grows on living or dead trees, stumps and fallen logs, causing a white rot. The typical habitats of this fungus are hollows and cracks of living trees, and $C$. varius has a certain pathogenic importance. Basidiomata exist during a single season (Jule-November), and, owing to their pliable context, rather quickly destroying by insects.

The most typical habitats of this fungus are old broadleaf stands, where it infests a hollows and cracks of the trees (Fig. 6). 


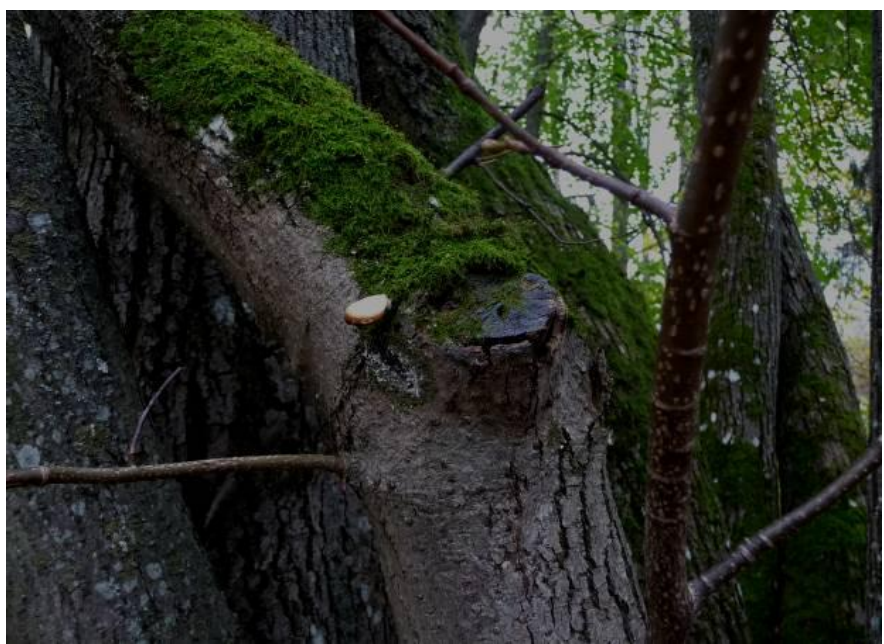

Figure 6. Typical habitat of Cerioporus varius in the Pushkin city.

Distribution. EUROPE: United Kingdom, Denmark, Norway, Sweden, Finland, Estonia, Latvia, Lithuania, Belgium, France, Germany, Austria, Poland, Czech Republic, Switzerland, Italy, Montenegro, Bulgaria, Romania, Ukraine, Belarus, Russia; ASIA: Russia, China, Taiwan, Japan; AUSTRALIA: Australia, New Zealand; NORTH AMERICA: USA, Canada; SOUTH AMERICA: Brazil, Chile (Global.., 2016).

Table 2. Records of Cerioporus varius on the Pushkin city (Tsarskoye Selo) territory

\begin{tabular}{|c|c|c|c|c|}
\hline $\mathrm{N}$ & Coordinates & Locality, habitat & Substrate & Specimen \\
\hline 1. & $\begin{array}{l}59^{\circ} 43^{\prime} 36^{\prime \prime} \mathrm{N}, \\
30^{\circ} 22^{\prime} 12^{\prime \prime} \mathrm{E}\end{array}$ & $\begin{array}{l}\text { Fermsky Park, } \\
\text { mixed old stand } \\
\text { with Fraxinus } \\
\text { excelsior, Tilia } \\
\text { platyphyllos, } \\
\text { Malus spp. }\end{array}$ & $\begin{array}{l}\text { Fraxinus } \\
\text { excelsior fallen } \\
\quad \log \end{array}$ & $\begin{array}{l}\text { Cerioporus varius } \mathrm{f} . \\
\text { circumpurpurascens } \\
\text { (LE 287633). }\end{array}$ \\
\hline 2. & $\begin{array}{l}59^{\circ} 43^{\prime} 51^{\prime \prime} \mathrm{N}, \\
30^{\circ} 23^{\prime} 25^{\prime \prime} \mathrm{E}\end{array}$ & $\begin{array}{l}\text { Vicinities of } \\
\text { Saint-Petersburg } \\
\text { State Agrarian } \\
\text { University, Tilia } \\
\text { cordata } \text { stands }\end{array}$ & $\begin{array}{l}\text { Living Tilia } \\
\text { cordata } \text { notch }\end{array}$ & $\begin{array}{c}\text { typical form } \\
-\end{array}$ \\
\hline 3. & $\begin{array}{l}59^{\circ} 44^{\prime} 12^{\prime \prime} \mathrm{N}, \\
30^{\circ} 24^{\prime} 24^{\prime \prime} \mathrm{E}\end{array}$ & $\begin{array}{c}\text { Great } \\
\text { Architecture } \\
\text { Massive, Tilia } \\
\text { cordata } \text { stands }\end{array}$ & $\begin{array}{l}\text { Living Tilia } \\
\text { cordata } \text { notch }\end{array}$ & $\begin{array}{c}\text { typical form } \\
-\end{array}$ \\
\hline 4. & $\begin{array}{l}59^{\circ} 42^{\prime} 09^{\prime \prime} \mathrm{N}, \\
30^{\circ} 24^{\prime} 08^{\prime \prime} \mathrm{E}\end{array}$ & $\begin{array}{l}\text { Novaya str., } \\
\text { public garden }\end{array}$ & $\begin{array}{c}\text { Living Aesculus } \\
\text { hyppocastanum } \\
\text { notch }\end{array}$ & $\begin{array}{c}\text { typical form } \\
\qquad-\end{array}$ \\
\hline 5. & $\begin{array}{l}59^{\circ} 42^{\prime} 45^{\prime \prime} \mathrm{N}, \\
30^{\circ} 23^{\prime} 29^{\prime \prime} \mathrm{E}\end{array}$ & $\begin{array}{l}\text { Catherine Garden, } \\
\text { Cascade ponds }\end{array}$ & $\begin{array}{l}\text { Living Tilia } \\
\text { cordata } \text { notch }\end{array}$ & $\begin{array}{c}\text { typical form } \\
-\end{array}$ \\
\hline
\end{tabular}




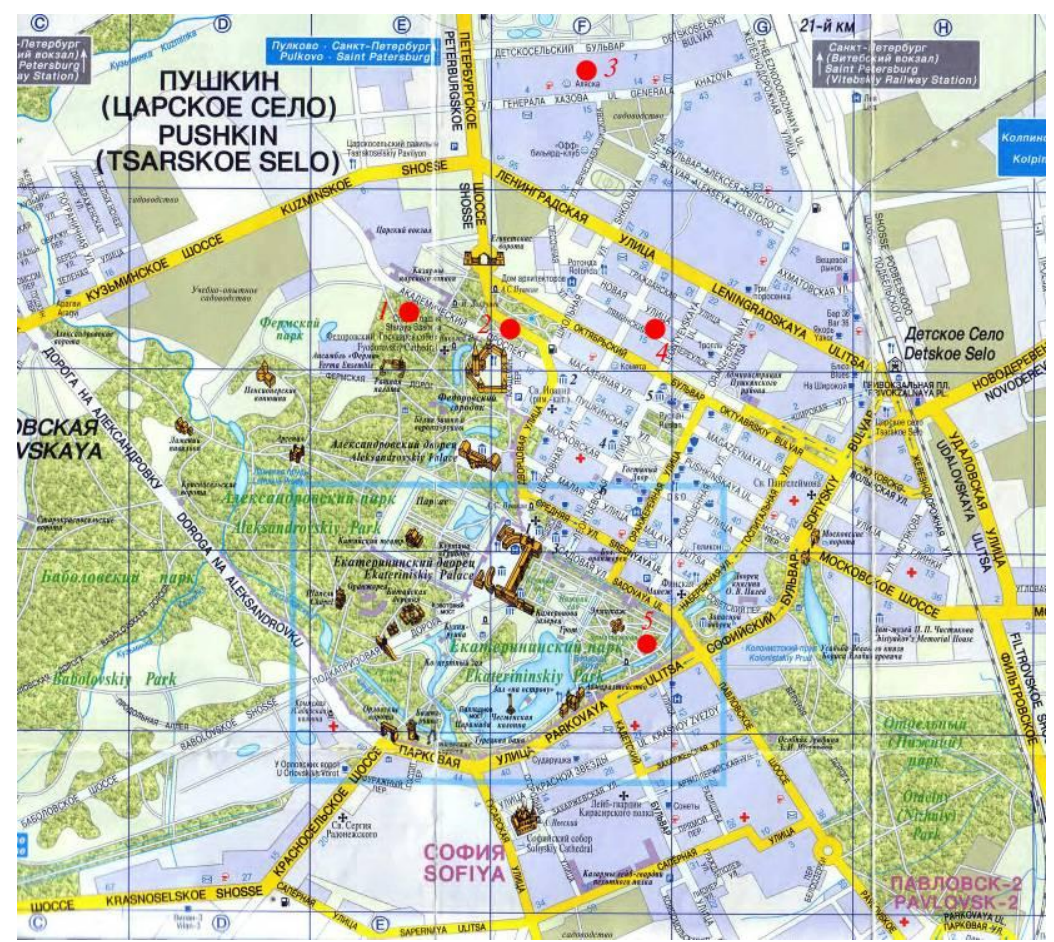

Figure 7. Pushkin city quarter plan with indications of habitats of Cerioporus varius (red circles). The numbers are corresponded to those in Table 2.

The distribution of this species over the Pushkin (Tsarskoye Selo) territory is scarce, too. Only 5 habitats of $C$. varius are revealed (Table 2; Fig. 7). All these are presented by broadleaf stands, where it is attached to notches and fallen logs of the trees.

\section{Morphological variability}

C. varius can be easily recognized due to its medium-sized minute basidiomes (basidiome clusters) with clay or pale ochraceous pilei on rather short wedge-shaped stipes. The margin upperside is easily colored in brownish or even purplish shades. Upperside is clay-colored, but can be reaching an ochraceous tints or decolorating to ivory-white colors. Something ridged surface is highly characteristic. The stipe in this species is rather short and a black crust is not characteristic for this species, but brown or blackish pruina can be oserved near stipe base.

There were described several forms among which, besides a type form, are most reliably recognizable the $C$. varius f. undulatolobatus (Bourdot et Galizn) Bondartseva, Zmitr. et Sidelnikova comb. nova (Bas.: Melanopus varius f. undulatolobatus Bourdot et Galzin, Bull. trimest. Soc. mycol. France 41(1): 111, 1925; MB 818685), distinguished by an undulating margin and not presented on the Pushkin area, and $C$. varius f. circumpurpurascens, which was found in the Pushkin city and is epitypified in the present report. 
Cerioporus varius f. circumpurpurascens (Pilát) Bondartseva, Zmitr. et Sidelnikova comb. nova. - Bas.: Polyporellus varius f. circumpurpurascens Pilát, Atlas Champ. L'Europe III 1: 109, 1937 (MB 818686).

Protolog ue: «Pileus minute, having an eccentric stipe, in a middle part faintly ochraceous, reddish-brown at the margin» (Pilát, 1937).

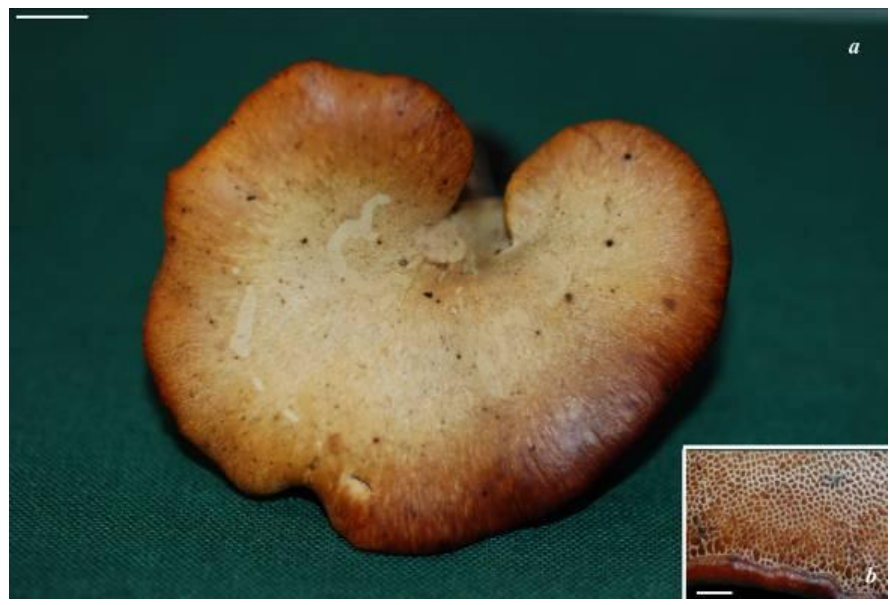

Figure 8. Cerioporus varius f. circumpurpurascens (LE 287603): $a$ - upperside of basidiome, $b$ - pores near the margin. Scale bar: $a-1 \mathrm{~cm}, b-1 \mathrm{~mm}$.

E p i t y p e: Russia, St. Petersburg, Pushkin city (Tsarskoye Selo), Fermsky Park, mixed old stand with Fraxinus excelsior, Tilia platyphyllos, Malus spp., on Fraxinus excelsior fallen log, 19.08.2016, coll. I. V. Zmitrovich (LE 287603).

Material description: Basidiome annual, solitary, differentiated into wide pileus and eccentric stem. Pileus $4.5 \mathrm{~cm}$ wide and $0.5 \mathrm{~cm}$ thick at the base, conchate (almost infundibuliform). Upper surface glabrous, covered with clay cuticle, of radially-fibrillose internal texture, even. Margin of castaneouspurplish-brown coloration ( $k 4 / n 4$ according to Bondartsev, 1954), more or less even in outline. Stipe $1.7 \mathrm{~cm}$ long and $-4 \mathrm{~mm}$ in cross-section, rather short, straight, lateral, covered with brownish-black pruina. Hymenophore as a single tube layer, $4.5 \mathrm{~mm}$ thick, well differentiated from the context; pore surface initially clay-buff; pores $4-5$ per $\mathrm{mm}$, roundish, thick-walled, isodiametric The context $-0.4 \mathrm{~mm}$ thick, homogeneous, dense, cream-colored. (Fig. 8).

The microstructure varies as in a neutral type. Basidiospores $8.9-10.5 \times$ $3.0-3.5 \mu \mathrm{m}$.

\section{CONCLUSION}

Two species, recorded in Pushkin city, C. varius and C. leptocephalus represent quite distinguishable component of polypore biota. The first species is mainly associated to old broadleaf stands, where infests a notches of living or fresh fallen trees. The second one is mainly associated to shrub understory of broadleaf massifs, where infests minor stumps and fallen branches of shrubs and 
trees. The differences between $C$. varius and $C$. leptocephalus lye rather in morphogenetic field and are comparable to another species pair, C. squamosus/C. rangiferinus: the second ones represent an arrhythmic phenotypes characterized by developed stipes and minute pilei. Until precise molecular testing, we prefer to consider both items as independent species adapted to specific microenvironment of temperate leaf forests.

\section{ACKNOWLEDGEMENTS}

The authors are very grateful to Prof. Lydia G. Perevedentseva for important notes on the manuscript. The work of M. A. Bondartseva and I. V. Zmitrovich was carried out in canvas of the program of the Russian Academy of Sciences «Biodiversity of nature systems. Biological resources of the Russia: an estimation and fundamental bases of monitoring», the nomination «Systematics and phylogeny of important groups of the Fungi in connection to the problem of fungal communities formation» and «Check-list of aphyllophoraceous fungi of European Russia».

\section{REFERENCES}

Bernicchia, A. (2010): Polyporaceae s. 1. Fungi Europaei. Ed. Candusso. 10. P. 1-808.

Bolton, J. (1790): An history of fungusses, growing about Halifax. Vol. 3. London. P. 93138.

Bondartsev, A. S. (1953): Tinder fungi (Polyporaceae s. 1.) of European part of USSR and Caucasus. Moscow-Leningrad. 1106 p. (in Russian).

Bondartsev, A. S. (1954): Colors' scale (A biologists' handbook for scientific and applied research). Moscow-Leningrad. 28 p. (in Russian).

Bondartseva, M. A. (1998): Definitorium fungorum Rossiae. Ordo Aphyllophorales. Fasc. 2. Familiae Albatrellaceae, Aporpiaceae, Boletopsidaceae, Bondarzewiaceae, Corticiaceae (genera tubuliferae), Fistulinaceae, Ganodermataceae, Lachnocladiaceae (genus tubiliferus), Phaeolaceae, Polyporaceae (genera tubuliferae), Poriaceae, Rigidoporaceae. Saint Petersburg, Nauka. 391 p. (in Russian).

Bondartseva, M. A., Kotkova, V. M., Zmitrovich, I. V. \& Volobuev, S. V. (2014): Aphyllophoroid and heterobasidial fungi of the Peter Great Botanical Garden of V. L. Komarov Botanical Institute of the Russian Academy of sciences (Saint Petersburg). In: Botany: History, theory, practice (to the 300-years anniversary of foundation of V. L. Komarov Botanical Institute of the Russian Academy of Sciences). St. Petersburg. P. 23-30 (in Russian).

Bulliard, P. (1787): Herbier de la France ou collection complète des plantes indigènes de ce royaume. Paris. Pl. 360.

Fries, E. M. (1821): Systema mycologicum. Vol. 1. Lund. 520 p.

Gilbertson, R. L. \& Ryvarden, L. (1987): North American polypores. Vol. 2. Port Jervis, Lubrecht \& Cramer. P. 434-886.

Global Biodiversity Information Facility (2016): http://www.discoverlife. org/mp/. Accessed 29.09.2016.

Hibbett, D. S., Bauer, R., Binder, M., Giachini, A. J., Hosaka, K., Justo, A., Larsson, E., Larsson, K. H., Lawrey, J. D., Miettinen, O., Nagy, L. G., Nilsson, R. H., Weiss, M. \& Thorn, R. G. (2014): Agaricomycetes. In: The Mycota. A comprehensive 
treatise on Fungi as experimental systems for basic and applied research / Ed. K. Esser. Heidelberg et al.: Springer, pp. 373-430.

Jacquin, N. J. (1778): Miscellanea Austriaca ad botanicam, chemiam, et historiam naturalem spectantia, cum figures partis coloratis. Vol. 1. Vindobon. 210 p., 21 pl.

Niemelä, T. (2005): Käävät: puiden sienet. Norrlinia 13: 1-320.

Overholts, L. O. (1953): The Polyporaceae of United State, Alasca and Canada. New York. 466 p.

Persoon C. H. (1796): Observationes mycologicae. Pars prima. Leipzig. P. 1-116.

Pilát, A. (1937): Polyporaceae. In: Atlas des champignons de l'Europe III. Vol. 1 / Ch. Kavina \& A. Pilát. Praha. P. 97-176.

Sowerby, J. (1897-1815): Colored figures of English fungi or mushrooms. Vol. 3 (1897). London. Tab. 1-120.

The Danish red data book. Taxon list (2016): http:// http://www2.dmu.dk/1_Om_DMU/2_Tvaerfunk/3_fdc_bio/projekter/redlist/artsgrupper_en.asp. Accessed 29.09.2016.

Zmitrovich, I. V. \& Kovalenko, A. E. (2016): Lentinoid and polyporoid fungi, two generic conglomerates containing important medicinal mushrooms in molecular perspective. Int. J. Medicinal Mushrooms 18(1): 23-38.

Zmitrovich, I. V. (2016): Noteworthy polypores of Pushkin city near the Saint Petersburg (Russia), the reserve of old-growth trees. 1. Trametes suaveolens. Agriculture and Forestry. Podgorica 62(2): 81-90.

Zmitrovich, I. V., Malysheva, V. F. \& Malysheva, E. F. (2009): Hyphal types of polyporoid and pleurotoid fungi: a terminological revision. Ukrainian Bot. J. 66(1): 71-87 (in Russian).

Zmitrovich, I. V., Malysheva, V. F., Kosolapov, D. A. \& Bolshakov, S. Yu. (2014): Epitypification and characterization of Polyporus choseniae (Polyporales, Basidiomycota). Mikilogiya i fitopatologiya 48(4): 224-230.

Zmitrovich, I. V., Volobuev, S. V., Parmasto, I. H. \& Bondartseva, M. A. (2017): Rehabilitiation of Cerioporus (Polyporus) rangiferinus, a sib of Cerioporus squamosus. Hova Hedwigia (in press). 